Chirurgia (2020) 115: 102-111

No. 1, January - February

Copyright@ Celsius

http://dx.doi.org/10.21614/chirurgia.115.1.102

\title{
Colonic Goblet Cell Carcinoid: Rarity of a Rarity! A Case Report and Review of Literature
}

\section{Abdalla Saad Abdalla Al-Zawi', Kashuf Arooj Khan², Ahmed Shah', Amira Asaad', Victoria Salter', Marina Barron ${ }^{4}$, Soad Eldruki ${ }^{5}$, Victoria Salih ${ }^{6}$, Salem Omar Alowami ${ }^{3}$}

${ }^{1}$ Basildon \& Thurrock University Hospital, Essex, UK

${ }^{2}$ Royal Shrewsbury and Telford Hospital, Shrewsbury, UK

${ }^{3}$ Department of Pathology, McMaster University, Hamilton, Ontario, Canada

${ }^{4}$ Royal Victoria Hospital, Belfast, UK

${ }^{5}$ Department of Pathology, Benghazi Medical Centre, Benghazi, Libya

${ }^{6}$ Department of Surgery, Kings College Hospital, London, UK

Corresponding author:

Abdalla SAAD ABDALLA, M.B.B.Ch,

SD in Surgery. PhD, FRCS

NHS Consultant Breast Surgeon

E-mail: abdalasaad@gmail.com

Abbreviations:

GCC - Goblet cell carcinoids;

NET - neuro-endocrine tumour;

IBD - inflammatory bowel disease;

EGD - esophagogastroduodenoscopy;

\section{Rezumat}

Carcinoid cu celule colonice goblet: o raritate! O prezentare de caz și o revizuire a literaturii

Carcinoizii cu celule goblet (GCC) sunt tumori neuroendocrine extrem de rare şi sunt caracterizate prin combinația lor unică de două tipuri de celule canceroase - neuroendocrine (carcinoide) şi epiteliale (adenocarcinom). În ciuda faptului că GCC este considerată tumoră neuro-endocrină (NET), nu prezintă sindromul carcinoid ilicit. GCC apare de obicei în anexă şi reprezintă mai puțin de $14 \%$ din toate tumorile apendiceale. GCC extraapendiceal primar a fost raportat la stomac, duoden, intestinul subțire, colon şi rect. Lucrarea prezintă un caz rar de GCC a colonului ascendent la un bărbat de 57 de ani.

Cuvinte cheie: carcinoid cu celule goblet, tumori neuroendocrine, glandă apocrină, celule care prezintă antigen

\section{Abstract}

Goblet cell carcinoids (GCC) are extremelyrare neuroendocrine tumours, and characterised by their unique combination of two types of cancer cells - neuroendocrine (carcinoid) and epithelial (adeno-carcinoma). In spite of the fact that GCC is regarded as Neuro-Endocrine Tumour (NET), it does not illicit carcinoid 
syndrome. GCC usually arises in the appendix and accounting for less than 14\% of all appendiceal tumours.Primary extra-appendiceal GCC have been reported as stomach, duodenum, small intestine, colon and rectum. The paper presents a rare case of GCC of the ascending colon in a 57-year-old male.

Key words: goblet cell carcinoid, neuroendocrine tumours, apocrine gland, antigen-presenting cells

\section{Introduction}

Goblet cell carcinoid (GCC) is a unique and rare tumour almost exclusively involving appendix with some exceptional locations elsewhere (1). GCC has been a topic of debate since it was first described by Gagne et al in 1969 due to its peculiar histology and biological variability. Consequently, this tumour has been adorned with various different names over the years however, currently all other names except for GCC have been excluded from World Health Organisation (WHO) classification (2). GCC is a hybrid mix of tumour constituting of both epithelial (adenocarcinoma) and neuroendocrine (carcinoid) components containing goblet cells. Current grading systems identify these tumours on the basis of a goblet cell carcinoid tumour containing features of adenocarcinoma, which is a distinguishing factor of this tumour from other gastrointestinal tract adenocarcinomas (3). Although it is commonly diagnosed incidentally following an appendicectomy or an ileocecal resection (4), due diligence should be applied to recognise and appropriately perform grading of these tumours due to their aggressive nature and metastatic potential (5). Prognosis is good if diagnosed in earlier stages with simple appendicectomy requiring for stage I,disease-specific 5-year survivals for stages I, II, III, and IV were $100 \%, 76 \%, 22 \%$, and $14 \%$, respectively with overall mean survival was $47 \pm 3$ months (6).

Appendiceal GCC is predominant in Caucasian population with mean age at diagnosis of 58, there is no variation in incidence between men and women (7). Development of GCC has not been associated with any particular risk factors (8). Another thing of note is despite its histological resemblance, this tumour does not illicit carcinoid syndrome.

Literature review using Pub Med search engine was performed using search term "Goblet Cell Carcinoid", majority of the articles published as of date described appendiceal GCC. Our study gives a detailed account of an extremely rare case of colonic GCC encountered in a 57-year-old male.

\section{Case Report}

We present a case of goblet cell carcinoid in a 57-year-old man that initially presented to the hospital with one episode of emesis and a $6^{-}$ week history of persistent lower abdominal cramping and pain. His past medical history includes 30 pack-year smoking history, $7 \mathrm{~g}$ weekly cannabis use, left hip arthroplasty and right knee meniscal repair. The patient has no family history of gastrointestinal malignancy, polyps or inflammatory bowel disease. He sought medical attention as he was unable to relieve his symptoms with over-the-counter analgesics including acetaminophen and ibuprofen. An outpatient ultrasound ordered by his family physician was suggestive of intussusception in his right abdomen, and he was advised to seek urgent medical attention. He presented to the emergency department where a CT scan demonstrated moderate-tosevere cecal wall thickening at the ileocecal valve with mucosal hyperenhancement extending to the terminal ileum, suggestive of inflammatory or infectious aetiologies, in particular inflammatory bowel disease (IBD). Several focal areas of mucosal hyper-enhancement and luminal narrowing were seen on $\mathrm{CT}$ 
(Fig. 1). However, due to the mass-like appearance of the abnormality, the differential also included a cecal neoplasm. Furthermore, there were multiple hyperenhancing mesenteric lymph nodes adjacent to the terminal ileum, and a prominent hyperenhancing linear structure adjacent to the posterior wall of the cecum measuring up to $1.1 \mathrm{~cm}$ in calibre that was suggestive of either inflammatory appendix, in particular Crohn's appendicitis, or an adjacent inflammatory lymph node (Fig. 1C). There was also luminal narrowing noted in keeping with low to moderate grade partial small bowel obstruction. Upon evaluation in the emergency department, the patient was discharged for urgent outpatient colonoscopy.

The following week, the patient received an esophagogastroduodenoscopy (EGD) and colonoscopy, which demonstrated obstruction in proximal ascending colon with circumferential firm thickening and reduced lumen diameter to approximately $5 \mathrm{~mm}$. At that time, patient reported worsening abdominal pain and distention, inability to tolerate solid oral intake, as well as his stool being more loose and stringy, and was therefore admitted for bowel obstruction. Shortly thereafter, he underwent right hemicolectomy, initially laparoscopically for the obstructing mass,
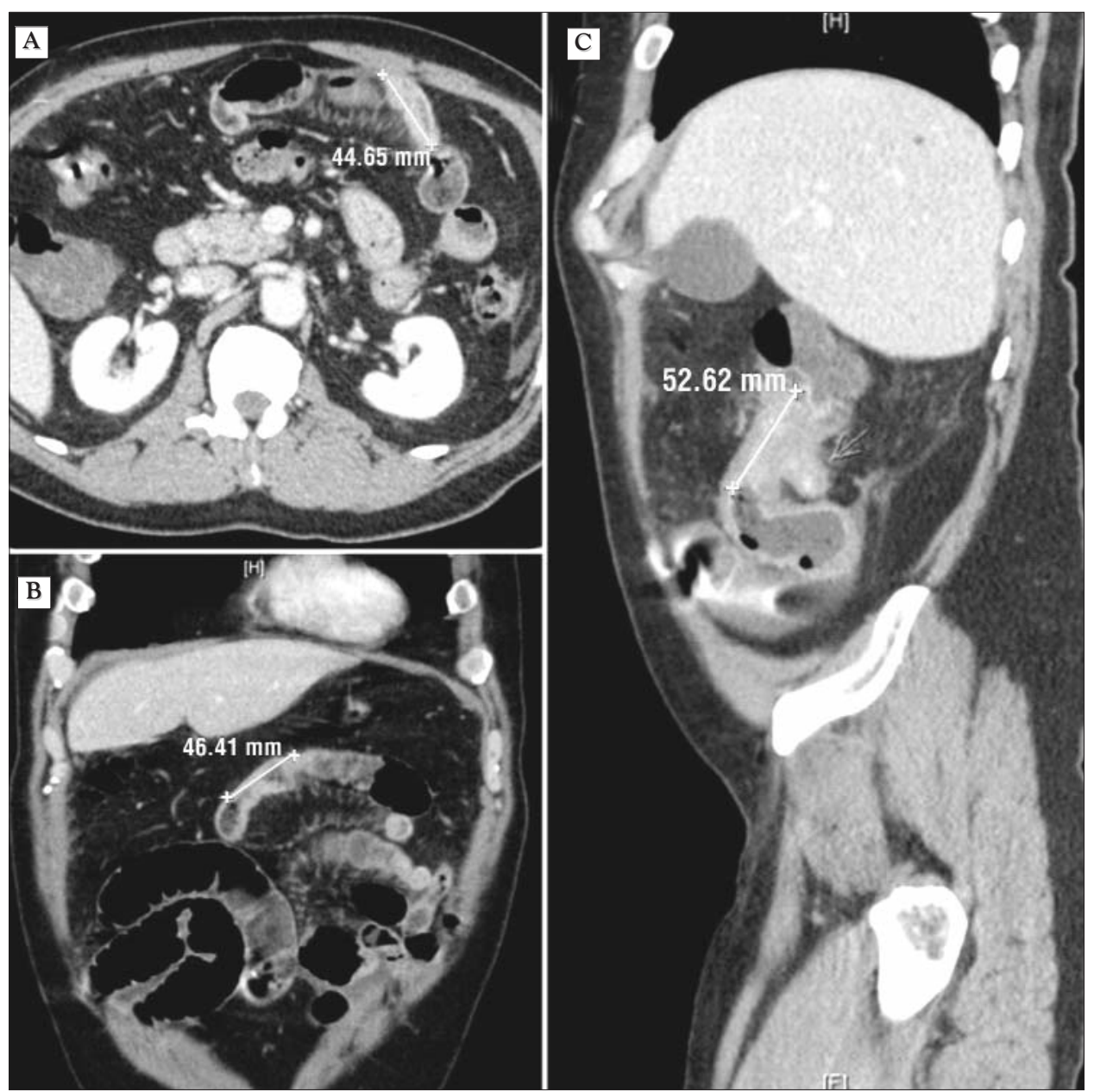

Figure 1. Abdominal CT images of mucosal hyperenhancement and luminal narrowing of the small bowel. (A) Axial plane. (B) Coronal plane. (C) Sagittal plane showing a linear hyperenhancing structure suspicious for appendicitis or inflamed lymph node, marked by green arrowhead. A green line is used to highlight the length of the hyper-enhanced small bowel lesions in millimetres ( $\mathrm{mm}$ ). 
which was converted to open for en-bloc resection of the right hemi-colon with anterior Gerota's fascia, as the mass was found to be invading the retroperitoneum.

Upon gross examination, the tumour was $4.7 \times 3.9 \times 4.5 \mathrm{~cm}$, firm, pale-tan circumferential mass with ill-defined borders, located in the ascending colon adjacent to and involving the ileocecal valve. The tumour had clear resection margins, but grossly appeared to penetrate through the serosal surface, combining with surrounding adipose tissue. The appendix was not grossly identified in the hemicolectomy specimen.

Microscopically, the tumour is seen infiltrating normal colonic glands as nests and small clusters of cells with small bland monomorphic nuclei with eosinophilic cytoplasm and abundant cytoplasmic mucin with signet cell morphology resembling goblet cells (Fig. 2). Serosal involvement, as well as lympho-vascular and perineural invasion was confirmed microscopically. Moreover, 17 out of 19 lymph nodes examined were involved. Immunohistochemically, the tumour cells positively reacted with neuroendocrine markers CD56 and synaptophysin (Fig. 3). Moreover, epithelial marker CAM 5.2 was also positive, as well as CK7, CK20, CDX2 (Fig. 3). The tumour also showed $30 \%$ of the cells cycling with Ki-67. Subsequently, the diagnosis of grade 3 , poorly differentiated goblet cell carcinoid, pT4a N2b, was made (Table 1).

\section{Discussion}

The gastro-intestinal epithelium is composed from various differentiated cell types, each type carries out unique and specialized functions.

Among these types, there is enterocytes, which are responsible for nutrient and water absorption, entero-endocrine cells that secrete hormones, the Paneth cells that release antimicrobial factors, the chemosensory tuft cells which play a key role in defense against helminths, $M$ cells which are responsible for presentation of luminal antigens to the immune system and goblet cells that secrete mucins.

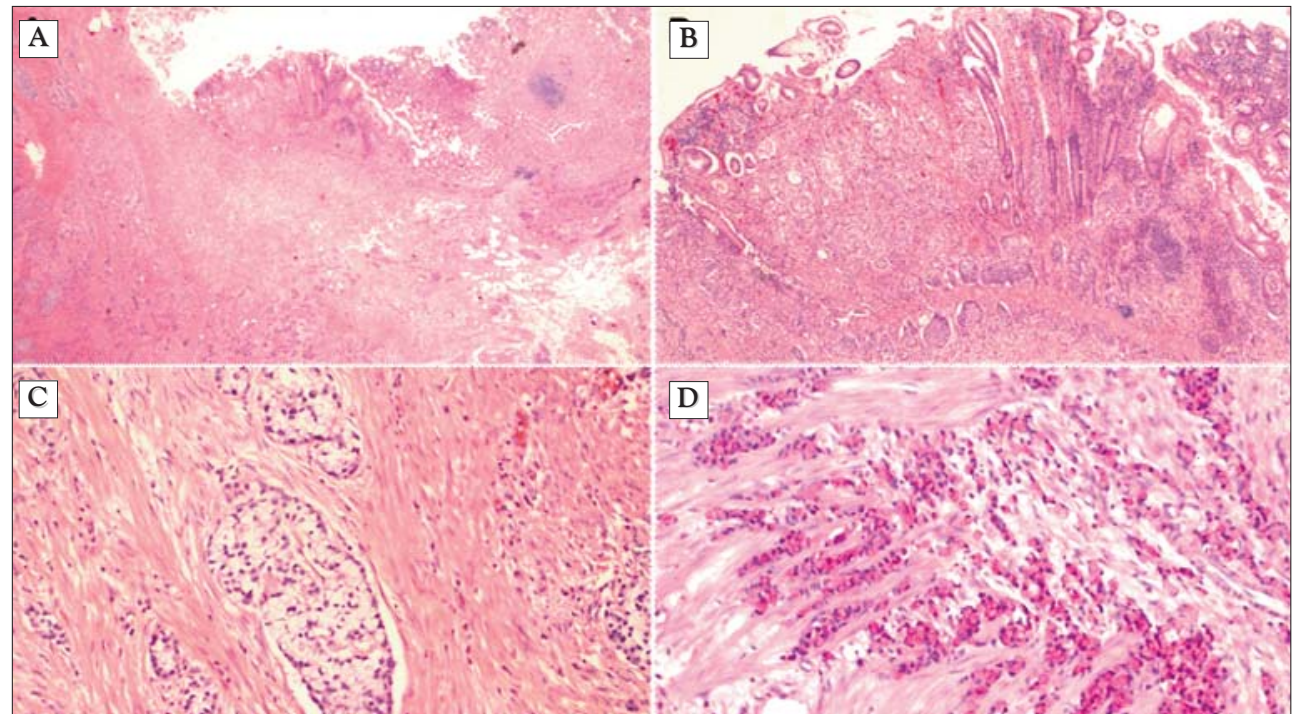

Figure 2. Representative morphological images of goblet cell carcinoid. (A) Tumour arising from mucosa and infiltrating through the muscularispropria, H\&E staining, x12.5 magnification. (B) Tumour arising from mucosa and infiltrating through submucosa, H\&E staining, $x 40$ magnification. (C) Tumour cells showing dark monotonous cells and cells with signet cell (goblet) morphology infiltrating the muscularispropria, H\&E, x200 magnification. (D) Signet cells showing cytoplasmic mucin highlighted by PASD (Periodic Acid-Schiff with Diastase staining, x200 magnification. 


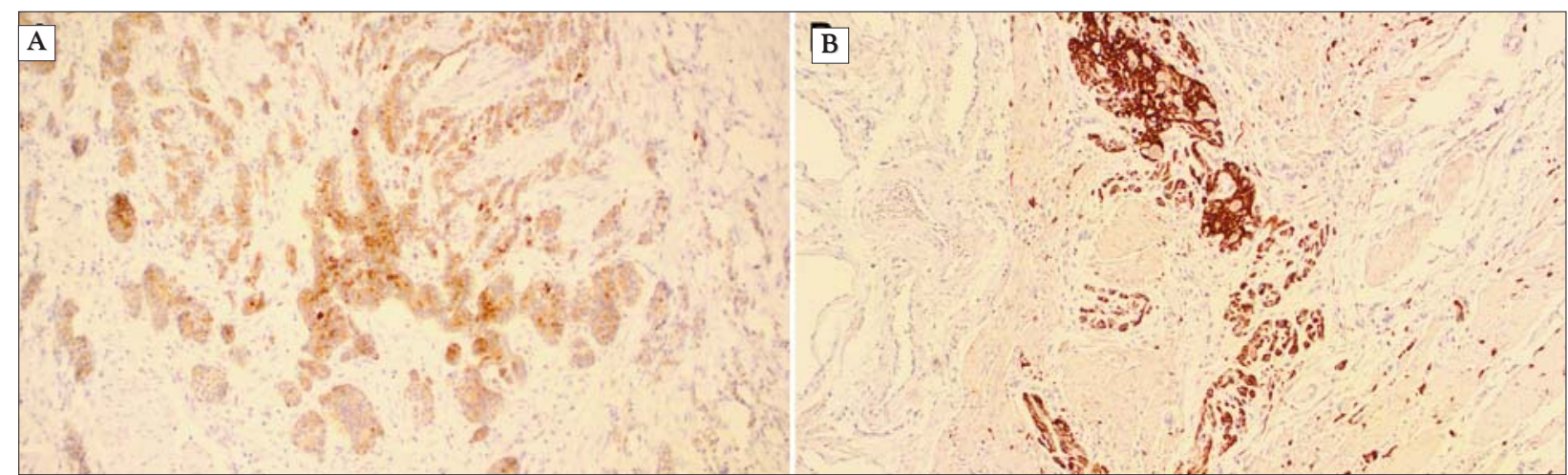

Figure 3. Representative images of immunohistochemistry of goblet cell carcinoid. (A) Tumour cells positive for epithelial marker CAM5.2, x100 magnification. (B) Tumour cells positive for neuroendocrine marker CD56, x100 magnification.

Generally speaking, the majority of cell types located in the colonare also found in the small intestine; these include the enterocytes

Table 1. Clinico-pathological characteristics of the presented case

\begin{tabular}{|c|c|}
\hline Age & 57 \\
\hline Gender & Male \\
\hline Presenting symptoms & Abdominal pain, vomiting \\
\hline Carcinoid syndrome & No \\
\hline Site & Ascending colon \\
\hline Gross appearance & $\begin{array}{l}37 \mathrm{~mm} \text {, firm mass with } \\
\text { ill-defined borders }\end{array}$ \\
\hline Serosal involvement & Yes \\
\hline \multicolumn{2}{|l|}{ Microscopic features } \\
\hline Morphology & $\begin{array}{l}\text { Nests and small clusters of } \\
\text { mucin cells mucin with signet } \\
\text { cell morphology resembling go } \\
\text { let cells }\end{array}$ \\
\hline Cytoplasm & Eosinophilic with abundant mucin \\
\hline Nuclei & Small bland monomorphic \\
\hline Lympho-vascular invasion & Present \\
\hline Perineural invasion & Present \\
\hline \multicolumn{2}{|l|}{ Staining } \\
\hline Mucincarmine/PAS* & Positive \\
\hline \multicolumn{2}{|l|}{$\mathrm{IHC}$} \\
\hline Synaptophysin & Positive \\
\hline Cam5.2 & Positive \\
\hline Cytokeratin-7 & Positive \\
\hline Cytokeratin-20 & Positive \\
\hline CDX-2 & Positive \\
\hline CD56 & Positive \\
\hline $\mathrm{Ki}-67$ & $30 \%$ \\
\hline Lymph nodes & Involved, 17 out of 19 \\
\hline
\end{tabular}

*PAS: Periodic acid-Schiff (also referred to as colonocytes in colon), entero-endocrine cells, goblet cells, and tuft cells (9).

The term goblet refers to the cell's gobletlike shape. The apical portion is shaped like a cup, the abundant mucus laden granules causing distention of the apical portion; its basal portion lacks these granules and is shaped like a stem (Fig. 4).

Goblet cells are typically found in the respiratory tract, reproductive system, gastrointestinal tracts and conjunctiva, usually are surrounded by other columnar epithelial cells $(10,11)$.

It has been well-documented how mucin, (high-molecular-weight glycoprotein produced by the goblet cells), is an integral component of both mucosal homeostasis and defence from infection. The mucin itself is functioning as a dynamic protective barrier to protect the intestinal mucosa, where mucus layer separates the underlying intestinal epithelium from luminal microbes. Mucins are the first molecules that interact with the invading pathogens and thus, can limit microbes binding to other glycoproteins and neutralize the pathogen (12).

Goblet cell is an exocrine glandular cell, uses mainly the merocrine (eccrine) pathway of secretion, secreting vesicles into a duct lumen by exocytosis (Fig. 4). However, some of them may use apocrine way of section by budding-off their secretions, where the apical portion of the secretory cell of the gland 


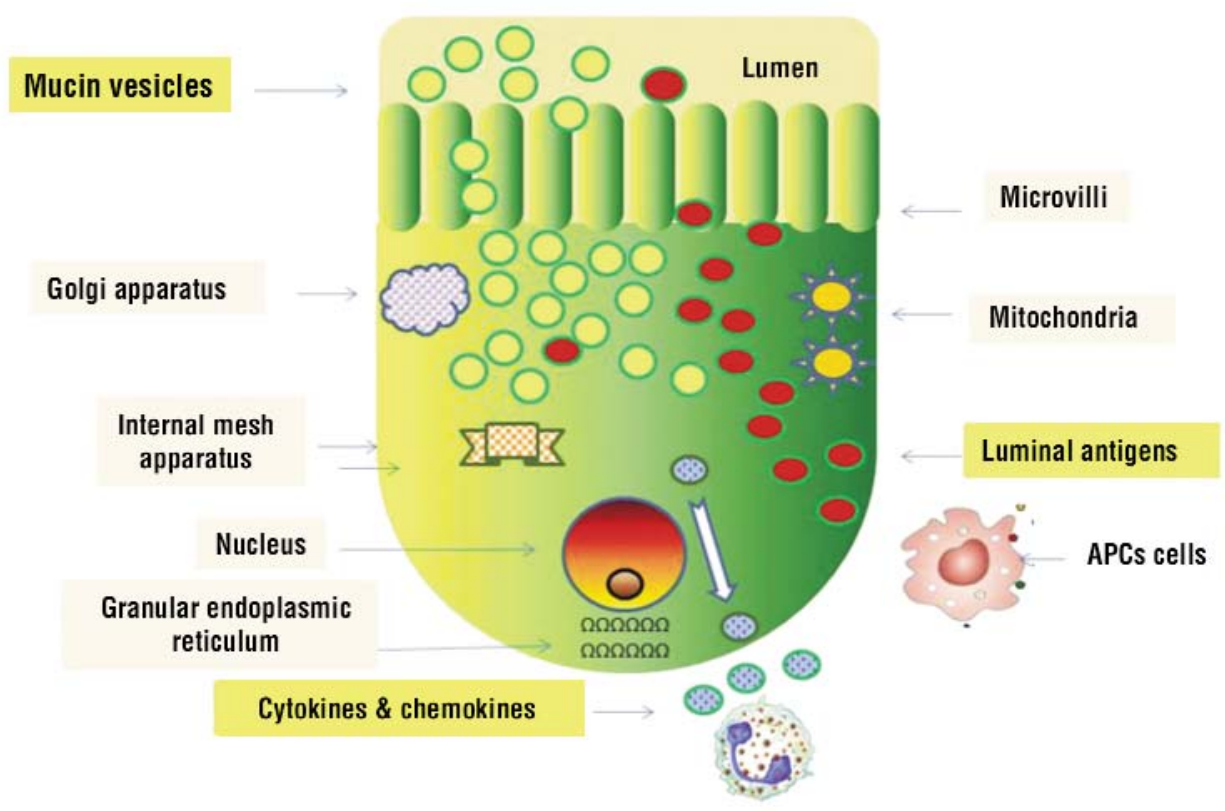

Figure 4. Function of Goblet cell, mucin production through merocrine pathway, goblet cell-associated antigen passages (GAP) to the antigen-presenting cells (APCs) cells and chemokines \& cytokines production.

*Adapted from Knoop et al, 2018 (11).

pinches off and enters the duct system lumen 2012 first demonstrated that small intestinal (Fig. 5). goblet cells are capable by endocytosis to pass

McDole et al from Washington University in antigens from the gut lumen through goblet

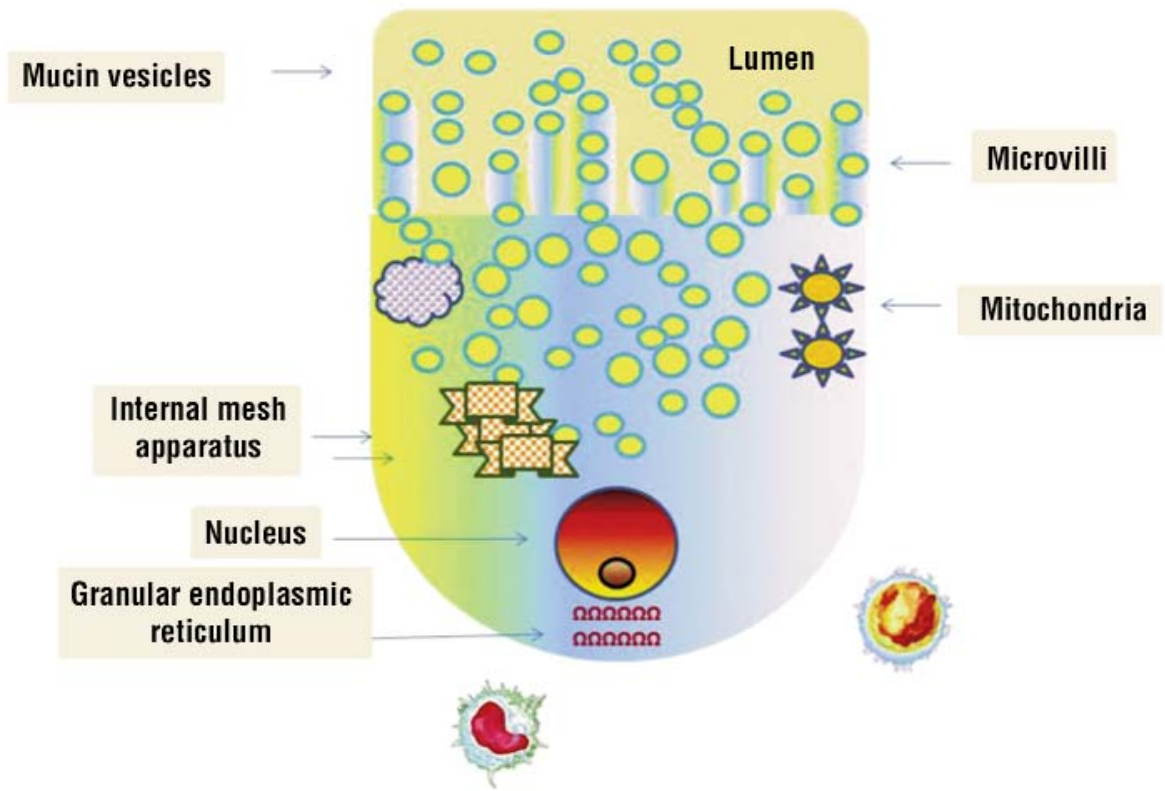

Figure 5. Apocrine secretory pathway, the apical portion of the secretory cell of the gland pinches off and enters the duct system lumen containing the mucin.

*Adapted from Knoop et al, 2018 (11). 
cell-associated antigen passages (GAP) to the dendritic lamina propria (LP) antigenpresenting cells (APCs) cells located deep to the basement membrane (Fig. 4), this results in inducing adaptive immune responses against the pathogens (13). Also the goblet cells secrete anti-microbial proteins, chemokines, and cytokines which play role in innate immunity beyond barrier maintenance function of the mucin (11).

Goblet cell carcinoid (GCC) is a rare tumour, was first described by Gagne in $1969(14,15)$, in addition World Health Organization accepted the term "mucinous carcinoid" as a name for this condition (16).

GCC usually occurs in 5th -6th decadeof life with median age at diagnosis of 58.9 years and no significant gender disparity $(17,18)$,it is characterized by mixed phenotype of dual neuroendocrine and glandular differentiation. The majority of primary malignant appendiceal tumours are carcinoid, followed by mucinous adenocarcinoma, GCC remains is as uncommon primary tumour of the appendix, and infrequent to occur elsewhere $(19,20)$. GCC has an estimated incidence of 1 per 2 million individuals, usually arises in the appendix and accounting for less than $14 \%$ of all appendiceal tumours $(16,18)$.

Goblet cell carcinoid has been regarded as a distinctive entity, not related to classic carcinoid tumours. A few cases of combined classic carcinoid and goblet cell carcinoid (GCC) tumour have been reported (morphologic variant believed to represent dual parallel differentiation although collision tumour (separate, independent primaries) must also be considered as a possibility (19).

There are rare cases of ostensibly primary extra-appendiceal GCC have been reported as stomach, duodenum, ampulla of Vater (21), jejunum, ileum, cecum, splenic flexure $(22,23)$, ascending colon (24) and rectum $(22,25,26$, 27,28).

Goblet cell carcinoid of the colon (GCCC) is rare, its clinical behaviour ranges from aggressive to relatively indolent disease. Treatment is based on tumour site,extent of the disease, histological tumour grade and individual patient characteristics (29).

The colorectal neuro-endocrine tumour (NET) including GCCC does not present with any specific symptoms, however maypresent with abdominal pain, large mass, constipation, intestinal obstruction, tenesmus, haematochezia or anal pain, however as other goblet cell carcinomas, GCCCs tumour does not illicit carcinoid syndrome. These tumours can be detected incidentally during routine investigations such as colonoscopy $(17,30,31,32)$.

Ulcerative colitis patients are at increased risk of mucosal dysplasia and colorectal malignancy development, NET has been reported to be diagnosed with a patients with a long history of ulcerative colitis, however this finding is extremely rare and only 14 cases have been documented between 1980 to 2015 (31).

GCC is also reported to be associated with Neurofibromatosis Type 1 as well as ovarian mucinous cystadenocarcinoma, it has been diagnosed concurrently with conventional colonic adenocarcinoma $(24,27,33)$.

Histologically, the bulk of the tumour is in the lamina propria or submucosal layer, there are two types of tumour cells; a relatively small to intermediate cells, with eosinophilic finely vacuolar or granular eosinophilic cytoplasm, vesicular round nuclei, prominent nucleoli, and mild cytologic atypia, reminiscent of typical carcinoids. The second type is the signet-ring-like (goblet) cellfilled with abundant cytoplasmic mucinand crescentic nuclei. Neoplastic cells formed small nests in a solid, cord-like, or glandular pattern separated by stroma or large pools of mucin $(1,27,28)$.

This condition should be differentiated from signet cell carcinoma, which a rare colonic neoplasm and characterized by cells with abundant intracytoplasmic mucin and peripherally placed nuclei, however it is negative with neuroendocrine immunohistochemistry markers. When signet ring cell adenocarcinoma is encountered in a colonic lesion, a colon primary is supported if the neoplastic cells have a cytokeratin $7(-) /$ cyto- $^{-}$ keratin $20(+)$ staining pattern, $(34,35,36)$.

Immunohistochemistry has a role in diag- 
nosis of GCC, Cytokeratin 7 (CK7) is a basic type II keratin of simple non-keratinizing epithelia protein, which shows strong expression in different epithelial tissues as breast, upper gastrointestinal tract, endometrium, urinarybladder, pancreas, biliary tract, and lungs $(37,38)$, it shows positivity in the carcinoids and up to $70 \%$ of the GCC cases $(39,40)$.

Cytokeratin-20 (CK20) is a sensitive marker for Merkel cell carcinoma (Positive in 90-100\% of cases), it also shows expression in some cases of extra-pulmonary small cell lung carcinoma (40). In GCC, up to $100 \%$ of cases exhibits positivity to CK20 (39).

CAM 5.2 is an immune-stain used to detect Cytokeratin 8(CK8) and Cytokeratin. It is positive in breast, lung, ovary and urothelium tissues. The neuro-endocrine cells are positive for Cam 5.2 stains $(41,42)$.

DCX2 is a homeobox gene that encodes a nuclear transcription factor critical for intestinal embryonic development; relatively specific for intestinal epithelium. It shows positive staining in carcinoid tumours (43).

Synaptophysin (Trans-membrane Channel Protein) is a common specific but not sensitive endocrine marker, it is used in carcinoid tumour, Merkel cell carcinoma (MCC) and small cell carcinoma $(3,32,40,44,45)$.

CD56 (Homophilic binding glycoprotein with role in cell-cell adhesion) is a common endocrine marker, it is a sensitive marker for MCC as well as for NK-cell lymphoma, however it lacks specificity (40). Neuroendocrine carcinomas are positive for CD56 $(5,46,47)$.

About $11.6 \%$ of GCCs patients presented with a distant metastatic disease at the time of diagnosis, other than the regional lymph nodes ovaries being the most common metastatic site, followed by peritoneal carcinomatosis (7).

The appendicular GCCs are more aggressive compared with conventional appendiceal tumours but less aggressive compared with adenocarcinomas, and they often present with serosal and meso-appendiceal involvement (2).

Whereas surgical resection of GCC remains the mainstay of resectable disease, chemotherapy options offered are 5-fluorouracil (5-FU) and leucovorin (LV) (28). Cytoreductive surgery (CRS) and intraperitoneal chemotherapy have been employed for the peritoneal disease $(29,32)$.

\section{Conclusion}

The colon is unusual site of goblet cell carcinoma, a very rare case of ascending colon goblet cell carcinoma has been described. For proper management pathway, colonic GCC should be differentiated from metastasis of appendiceal GC. Another differential diagnosis is signet ring cell carcinoma, which usually forms luminal space and is negative for immunohistochemistry markers. More research is neededto achieve better understanding of the biologic characteristics and implement optimal treatment strategies for this rare neoplasm.

\section{Acknowledgment}

We would like to thank Rihana SAAD ABDALLA from the BMAT STEM Academy School, in Harlow-England and Jakub SAAD ABDALLA from the Pemberley Academy Primary School in Harlow-England for their extra-ordinary work to prepare some of the included figures.

\section{Author's Contributions}

All authors contributed equally to the manuscript.

\section{Conflict of Interest}

The authors declare no conflicts of interests.

\section{References}

1. Roy P, Chetty R. Goblet cell carcinoid tumours of the appendix: An overview. World J Gastrointest Oncol. 2010;2(6):251-258.

2. Pickhardt PJ, Levy AD, Rohrmann CA, Jr, Kende Al. Primary neoplasms of the appendix: radiologic spectrum of disease with pathologic correlation. Radiographics. 2003;23:645-662.

3. Yozu M, Johncilla ME, Srivastava A, Ryan DP, Cusack JC, Doyle L, et al. Histologic and Outcome Study Supports Reclassifying Appendiceal Goblet Cell Carcinoids as Goblet Cell Adenocarcinomas, and Grading and Staging Similarly to Colonic Adenocarcinomas. Am J Surg Pathol. 2018; 42(7):898-910.

4. Lamarca A, Nonaka D, Lopez Escola C, Hubner RA, O'Dwyer S, 
Chakrabarty B, et al. Appendiceal Goblet Cell Carcinoids: Management Considerations from a Reference Peritoneal Tumor Service Centre and ENETS Centre of Excellence. Neuroendocrinology. 2016;103(5): 500-517.

5. Gilmore G, Jensen K, Saligram S, Sachdev TP, Arekapudi SR Goblet cell carcinoid of the appendix - diagnostic challenges and treatment updates: a case report and review of the literature. J Med Case Rep. 2018; 12(1):275.

6. Pham TH, Wolff B, Abraham SC, Drelichman E. Surgical and chemotherapy treatment outcomes of goblet cell carcinoid: a tertiary cancer center experience. Ann Surg Oncol. 2006;13(3): 370-376.

7. Pahlavan PS, Kanthan R. Goblet cell carcinoid of the appendix World J Surg Oncol. 2005;3:36.

8. Jiang $\mathrm{Y}$, Long $\mathrm{H}$, Wang $\mathrm{W}$, Liu $\mathrm{H}$, Tang $\mathrm{Y}$, Zhang $\mathrm{X}$. Clinicopathological features and immunoexpression profiles of goblet cell carcinoid and typical carcinoid of the appendix. PatholOncol Res. 2011;17(1):127-132.

9. Allaire JM, Crowley SM, Law HT, Chang SY, Ko HJ, Vallance BA .The Intestinal Epithelium: Central Coordinator of Mucosal Immunity.Trends Immunol. 2018;39(9):677-696.

10. Hodges RR, Dartt DA. Conjunctival Goblet Cells. Encyclopedia of the Eye. 2010:369-376.

11. Knoop KA, Newberry RD. Goblet cells: multifaceted players in immunity at mucosal surfaces. Mucosal Immunology. 2018;11: 1551-1557.

12. Kim JJ, Khan WI. Goblet Cells and Mucins: Role in Innate Defense in Enteric Infections. Pathogens. 2013;2:55-70

13. McDole JR, Wheeler LW, McDonald KG, Wang B, Konjufca V, Knoop KA, et al. Goblet cells deliver luminal antigen to CD103 dendritic cells in the small intestine. Nature. 2012;483(7389): 345-9.

14. Gagné F, Fortin P, Dufour V, Delage C. Tumeurs de I'appendice associant des caractèreshistologiques de carcinoïde et d'adénocarcinome (Tumors of the appendix associating histologic features of carcinoid and adenocarcinoma). Ann Anat Pathol (Paris). 1969; 14(4):393-406.

15. Wang YT, Li YR, Ke TY. Adenocarcinoma Ex Goblet Cell Carcinoid of Appendix: Two Case Reports. Case Rep Pathol. 2017;2017: 5930978.

16. NORD. National Organisation of Rare Diseases. https://rarediseases.org/rare-diseases/goblet-cell-carcinoid/. Visited on 25 Nov 2019

17. Afroz N, Shamim N, Sofi LA, Rizvi SAA. Incidentally discovered goblet cell carcinoid clinically presenting as acute intestinal obstruction: A case report with review of literature. Indian Journal of Microbiology and Pathology. 2014;57(1):120-123.

18. Goede AC, Caplin ME, Winslet MC. Carcinoid tumour of the appendix. British Journal of Surgery 2003. 90 1317-1322.

19. Chetty R, Klimstra D, Henson D, Albores-Saavedra J. Combined Classical Carcinoid and Goblet Cell Carcinoid Tumour: A New Morphologic Variant of Carcinoid Tumour of the Appendix.The American Journal of Surgical Pathology. 2010;34(8):1163-1167.

20. Abdalla AL-Zawi AS, Lazarevska A, Omer M, Lange Ratajczak M, Abohamod E, Tan E. Adenocarcinoma of the appendix mimicking acute appendicitis: A case report and literature review. EJPMR. 2018:5(3):104-107

21. Shibuya H, Hijioka S, Mizuno N, Kuwahara T, Okuno N, Tanaka T, et al. A Rare Case of Ampullary Goblet Cell Carcinoid. Intern Med. 2018:57(17):2489-2496.

22. Gui X, Qin L, Gao Z-H, Falck V, Harpaz N. Goblet cell carcinoids at extra-appendiceal locations of gastrointestinal tract: An underrecognized diagnostic pitfall. Journal of Surgical Oncology 2011; 103(8):790795.

23. Gupta A, Patel T, Dargar P, Shah M. Metastatic appendiceal goblet cell carcinoid masquerading as mucinous adenocarcinoma in effusion cytology: A diagnostic pitfall. J Cytol. 2013;30(2):136-138.

24. Jang KY, Park HS, Noh SJ, Lee H, Lee MR. Adenocarcinoma ex-goblet cell carcinoid of the ascending colon concurrent with conventional adenocarcinoma. Pathology. 2018:50(7):789-792.

25. Yamabuki T, Omi M, Yonemori A, Hayama S, Murakami S, Inomata $\mathrm{H}$, et al. Goblet cell carcinoid of the rectum with lymph node metastasis: Report of a case. Surg Today. 2011;41(9):1284-9.

26. Ishii Y, WakagiK, Ishizawa S, Kiya C, Masayoshi Sugawara. A Case of Goblet Cell Carcinoid of the Rectum. Journal of Japanese Society of Clinical Cytology. 2001;40 (6):616-62.

27. Kang Y, Choi JW, Kim Y, Oh HE, Lee JH, Kim YS. Goblet Cell Carcinoid of the Rectum in a Patient with Neurofibromatosis Type 1. J PatholTransl Med. 2016;50(6):482-485.

28. Wakahara T, Yamamoto S, Shin Fujita, Akasu T, Onouchi S, Moriya Y. A Case of Advanced Rectal AdenocarcinoidTumor with Longterm Survival. Japanese Journal of Clinical Oncology. 2010;40(7): 690-693.

29. Ibrahim U, Valecha G, Garcia G, Saqib A, Wrzolek M, Dhar M. Adenocarcinoma Ex-goblet Cell Carcinoid of the Appendix: a Case Report and Overview of the Disease. J Gastrointest Cancer. 2018; 49(4):497-500.

30. Shah R, Nalamati SPM. Neuroendocrine tumors of the colon and rectum. Seminars in Colon and Rectal Surgery. 2015;26(2): 60-63.

31. Rifu K, Koinuma K, Horie H, Morimoto M, Kono Y, Tahara M, et al. Sigmoid colon carcinoma with focal neuroendocrine differentiation associated with ulcerative colitis: A case report. Int J Surg Case Rep. 2016;23:151-6.

32. Youn SI, Namgung H, Yun JS, Park YJ, Park DG. Peritoneal Metastatic Goblet-Cell Carcinoid Tumor Treated With Cytoreductive Surgery and Intraperitoneal Chemotherapy. Ann Coloproctol. 2015;31(2):74-8.

33. GregersenT, Holt N, Gronbaek H, Vogel I, Jørgensen LJ, Krogh K. Goblet cell carcinoid in a patient with neurofibromatosis type 1: a rare combination. Case Rep Gastrointest Med. 2012;2012:185730.

34. Fu KI, Sano Y, Kato S, Saito H, Ochiai A, Fujimori T, et al. Primary signet-ring cell carcinoma of the colon at early stage: a case report and a review of the literature. World J Gastroenterol. 2006;12(21): 3446-9.

35. Goldstein NS, Long A, Kuan SF, Hart J. Colon signet ring cell adenocarcinoma: immunohistochemical characterization and comparison with gastric and typical colon adenocarcinomas. Appl Immunohistochem Mol Morphol. 2000;8(3):183-188.

36. Park PY, Goldin T, Chang J, Markman M, Kundranda MN. SignetRing Cell Carcinoma of the Colon: A Case Report and Review of the Literature. Case Rep Oncol. 2015;8(3):466-471.

37. Abdalla Al-Zawi AS, Ratajczak A, Idaewor P, Elamass M, Lazarevska A, Tan E, et al. Primary lung cancer with metastasis to the ipsilateral breast-a case report. Int J Res Med Sci. 2018;6(1):334-339.

38. Abdalla Al-Zawi AS, Lazarevska A, Murwan Omer M, Tan E, A Asaad E, Sathananthan S. Metastatic Breast Cancer to the Cervix Presenting with Abnormal Vaginal Bleeding During Chemotherapy: A Case Report and Literature Review. Chirurgia (Bucur). 2018; 113(4):564-570.

39. Alsaad KO, Serra S, Schmitt A, Perren A, Chetty R. Cytokeratins 7 and 20 immunoexpression profile in goblet cell and classical carcinoids of appendix. Endocr Pathol. 2007;18(1):16-22.

40. Abdalla Al-Zawi AS, Prodromou A, Chicken W, Comez T, Deniz E. Merkel cell carcinoma: literature review. Nowotwory Journal of Oncology. 2017;67(1):127-131.

41. Huang J, Yao JL, di Sant'Agnese PA, Yang Q, Bourne PA, Na Y. Immunohistochemical characterization of neuroendocrine cells in prostate cancer. Prostate. 2006;66(13):1399-1406.

42. Abdalla Al-Zawi AS, Lange-Ratajczak M, Chicken W, Karamanakos $\mathrm{S}$, Idaewor P, Elamass M. Pyloric metastases from primary breast 
cancer - a case report and literature review. JMSCR. 2017;05(11): 30098-30105.

43. Schmitt AM, Riniker F, Anlauf M, Schmid S, Soltermann A, Moch H, et al. Islet 1 (Isl1) expression is a reliable marker for pancreatic endocrine tumors and their metastases. Am J Surg Pathol. 2008; 32(3):420-5.

44. Abdalla Al-Zawi AS, Ratajczak A, Eldruki S, Zastawna K, Tan E. Merkel cell carcinoma in a patient with previous history of breast cancer: a case report and literature review. Int J Med Res Prof. 2018;4(1);313-16.
45. Miller DC, Koslow M, Budzilovich GN, Burstein DE. Synaptophysin: a sensitive and specific marker for ganglion cells in central nervous system neoplasms. Hum Pathol. 1990;21(3):271-6.

46. Livoff A, Asna N, Gallego-Colon E, Daum AZ, Harkovsky T, Schaffer M. Goblet cell carcinoid of the appendix: Two case reports and a review of the literature. Mol Clin Oncol. 2019; 11(5):493-497.

47. Bryson GJ, Lear D, Williamson R, Wong RC. Detection of the CD56+/CD45- immunophenotype by flow cytometry in neuroendocrine malignancies. J ClinPathol. 2002;55(7):535-537. 